\title{
Peter J. Boettke, Alexander William Salter, and Daniel J. Smith: Money and the rule of law: Generality and predictability in monetary institutions
}

\section{Cambridge University Press, New York, NY, 2021, xviii + 193 pp, USD 29.99 (paperback)}

\section{Bryan Cutsinger ${ }^{1}$}

Published online: 2 February 2022

(C) The Author(s), under exclusive licence to Springer Science+Business Media, LLC, part of Springer Nature 2022

Reviewing contemporary monetary policy research reveals a troubling asymmetry. It is dominated by technical discussions regarding models, data, and the array of tools that central banks possess, while issues of governance receive comparatively little attention. In Money and the Rule of Law, Peter Boettke, Alexander Salter, and Daniel Smith argues that this asymmetry reflects a failure on the part of the economics profession to grapple seriously with the political economy of discretionary central banking.

Boettke, Salter, and Smith's book provides a classical liberal perspective on monetary institutions. This perspective takes seriously the knowledge and incentive problems inherent in central banking, and thus rejects the romantic vision of policymaking that dominates much of the monetary and macroeconomic literature. This perspective recognizes that every conceivable monetary system involves tradeoffs. In consequence, ascertaining which system is most likely to promote sound money requires comparative institutional analysis to identify the strengths and weaknesses of the feasible alternatives. Finally, this perspective stresses the importance of general and predictable rules, which serve as the normative standard to which any monetary system must conform.

The authors argue that the current way of dealing with issues of central bank governance, a framework known as constrained discretion, is impracticable. In this framework, the monetary authorities are free to pursue short-run objectives provided they publicly pre-commit to a nominal target. In principle, this commitment is supposed to anchor the public's expectations of the central bank's future behavior. Boettke, Salter, and Smith contend that the trouble with constrained discretion is that it places insurmountable epistemic burdens on the monetary authorities by requiring them to possess knowledge that does not exist in the form necessary to guarantee monetary stability. Moreover, they argue that constrained discretion fails to account for the internal and external pressure on central bankers to pursue objectives inconsistent with the public interest.

Bryan Cutsinger

bryan.cutsinger@angelo.edu

1 Norris-Vincent College of Business, Angelo State University, San Angelo, TX 76909, USA 
As Boettke, Salter, and Smith explain, effective monetary policy requires maintaining, or at least closely approximating monetary equilibrium. They identify two types of knowledge problems that prevent discretionary regimes from achieving this goal. The first type consists of technical problems, which could, in principle, be overcome with improved models and data. These problems concern the objectives of monetary policy and the relative weights that should be given to conflicting objectives, the choice of appropriate targets and instruments to achieve those objectives, and the challenges associated with modeling the relationship between all three. As the authors note, however, that these problems are solvable in principle does not mean that they have been solved in practice.

The second, and more fundamental limitation consists of genuine knowledge problems stemming from the lack of feedback mechanisms that produce the knowledge necessary to achieve monetary equilibrium, which requires real-time knowledge of the public's demand for money. Boettke, Salter, and Smith note the range of technical problems associated with estimating the demand for money, particularly in the short run, but argue that these problems are secondary to the challenge of identifying which assets the public regard as money. The economy's stock of monetary assets is constantly evolving in response to financial innovation and regulation. In consequence, measuring the demand for money in real time in a manner that is sufficiently reliable for discretionary policymaking is not possible.

Boettke, Salter, and Smith note that the challenge of estimating the demand for money is made more difficult by the possibility of productivity shocks. Ideally, central banks would not respond to changes in productivity provided such changes did not affect the demand for money. As the authors note, however, monetary policymakers lack the real-time knowledge necessary to distinguish between changes in aggregate demand and supply conditions, let alone the ability to forecast productivity changes, which are often random. As a result, policymakers may inadvertently destabilize the economy either via excessive, or insufficient, monetary stimulus.

In the authors' view, these knowledge problems produce uncertainty about the optimal policy, which creates space for both internal and external pressures to influence policymakers in ways that are at odds with the public interest. They argue that the monetary policy literature has failed to account for these pressures when devising models of optimal central-bank behavior, which renders such models useless for dealing with the real world. The source of this oversight, the authors contend, is economists' discomfort acknowledging that they, too, respond predictably to incentives.

To illustrate just how powerful these incentives can be, Boettke, Salter, and Smith contrast the views of three former Federal Reserve (Fed) chairmen-Arthur Burns, Alan Greenspan, and Ben Bernanke-before they served on the Board of Governors with the policies they adopted during their tenure as chairmen. In each case, their actions belied their earlier views. They argue that this inconsistency was not the product of character flaws on the part of Burns, Greenspan, and Bernanke, who, the authors rightly note, are world-class economists, but was rather the product of bureaucratic and political incentives inherent in the institution of central banking.

The authors note that the Fed is plagued by the same problems that plague other bureaucracies, namely budget-maximizing behavior, self-preservation, inertia, and groupthink, and that these problems are amplified by the Fed's ability to self-finance. Unlike other government agencies, the Fed's budget is under the control of Fed officials, who can increase the central bank's revenue by creating reserves that can be used to expand its portfolio of assets. This peculiar feature of the Fed creates an incentive for monetary policymakers to unnecessarily expand the central bank's balance sheet to fund higher salaries, additional staff, etc. 
As Boettke, Salter, and Smith explain, however, the central bank's financial independence does not insulate it from political influence, especially considering the effects that monetary policy can have on the outcomes of electoral politics. Pressure from the executive and legislative branches, as well as pressure from interest groups, influence monetary policy in ways that harm the economy. The authors provide several historical examples that illustrate the effects of external pressure on monetary policy, which casts doubt on the widely held belief that the Fed is politically independent.

Taken together, the internal and external pressures make it unlikely that policymakers will use discretion in a manner consistent with optimal monetary policy. Boettke, Salter, and Smith argue that our models of monetary policy, and more importantly the design of our monetary institutions, must confront these incentive problems directly rather than ignoring them by assuming that because our monetary authorities tend to be accomplished economists they will always opt for optimal policy. The only solution, the authors contend, is to constrain the monetary authorities with binding rules, imposed and enforced from outside the central bank.

The authors recognize that while many readers will agree with their diagnosis of the problems that plague discretionary central banking, few will support binding the monetary authorities to a rule during periods of severe economic distress. A common argument against strict adherence to a monetary rule is that doing so prevents the monetary authorities from responding appropriately to financial crises because such events are difficult to predict and vary in their specifics. The authors concede that an ideally managed central bank would be superior to an ideal monetary rule. They note, however, that we do not live in an ideal world.

To illustrate this tradeoff, the authors compare the Fed's response to the 2008 financial crisis to Bagehot's rules, which are considered by many economists and monetary policymakers to be the ideal response to such an event. These rules, named after the $19^{\mathrm{th}}$-century British writer Walter Bagehot, state that central banks should lend freely on good collateral to solvent banks at a penalty rate high enough to limit moral hazard. This policy, Bagehot held, should be announced in advance to anchor the public's expectations of how the central bank would respond to a financial crisis.

Boettke, Salter, and Smith argue that the Fed's response to the financial crisis was inconsistent with Bagehot's rules, despite Fed officials' claims to the contrary. The Fed accepted risky collateral, like mortgage-backed securities, and lent to insolvent firms like AIG and Citigroup. Moreover, Fed officials never specified in advance the conditions under which financial institutions would be eligible for emergency loans, nor did they use their emergency lending authority consistently, as illustrated by the decision to bailout Bear Stearns but not Lehman Brothers. In the authors' view, the Fed's failure to follow Bagehot's rules has undermined the central bank's credibility, thereby making future financial crisis more likely.

The authors contend that the underlying reason Fed officials failed to respond appropriately to the financial crisis stems from the institutional context within which the monetary authorities make decisions. In their view, ideal policy will never emerge from this context owing to the knowledge and incentive problems inherent to the nature of discretionary central banking. The solution, the authors claim, is a robust monetary framework that will work well under less-than-ideal circumstances. Developing such a framework requires confronting the knowledge and incentive problems directly by explicitly incorporating these factors into the design of our monetary institutions.

Boettke, Salter, and Smith illustrate how these factors can be addressed by highlighting the work of F.A. Hayek, Milton Friedman, and James Buchanan. All three viewed the 
root cause of the problems with central banking as being institutional in nature. While Hayek and Friedman were initially optimistic that discretionary central banking could be improved through technical refinements, Buchanan was focused on institutional problems and solutions throughout his career. Despite these differences, the authors point out that Hayek, Friedman, and Buchanan each took the knowledge and incentive problems seriously and sought to incorporate solutions to these problems into their policy proposals.

The authors argue that one consequence of economists' failure to address these institutional issues directly is that monetary policy, as it is currently practiced in the United States, is inconsistent with the rule of law. In the context of monetary policy, the rule of law requires the Fed's actions to be both general and predictable. Generality requires the monetary authorities to treat all firms the same regardless of their political importance. The Fed's failure to do so, the authors argue, has created an incentive for firms to become politically connected, which wastes resources and exacerbates moral hazard problems. Predictability requires the monetary authorities to commit in advance to a particular behavioral pattern so that the public can be certain of what actions the authorities will take under a range of circumstances. As the Fed's response to the financial crisis illustrated, monetary policy has failed to live up to the rule of law.

This book could not have come at a more important time. Over the past two years we have witnessed agencies at all levels of government wield power in a manner inconsistent with the rule of law, and the Fed has been no exception. Milton Friedman believed that only crises bring about real change. The way in which we respond to such events, he argued, depends on the ideas lying around. Let us hope that as we evaluate the Fed's response to the COVID-19 pandemic, and contemplate what, if any changes we wish to make to our monetary institutions, we take seriously the ideas in Money and the Rule of Law.

Publisher's Note Springer Nature remains neutral with regard to jurisdictional claims in published maps and institutional affiliations. 